\title{
ASYMBIOTIC SEED GERMINATION AND PLANTLET DEVELOPMENT OF Dendrobium spectabile (Blume) Miq.
}

\section{Perkecambahan asimbiotik biji dan perkembangan planlet Dendrobium spectabile (Blume) Miq.}

\author{
Eka Martha Della Rahayu*, Melza Mulyani \\ Research Center for Plant Conservation and Botanic Gardens \\ Indonesian Institute of Sciences \\ Jl. Ir. H. Juanda No. 13, Bogor, West Java, 16003, Indonesia \\ *Email: emdrahayu@gmail.com
}

Diterima/Received: 5 Januari 2020; Disetujui/Accepted: 29 Maret 2020

\begin{abstract}
Abstrak
Dendrobium spectabile (Blume) Miq. merupakan salah satu jenis anggrek terancam punah dari Papua yang memiliki nilai ekonomi. Saat ini, protokol optimal untuk perkecambahan biji $D$. spectabile secara asimbiotik dan pengembangan planletnya belum tersedia. Penelitian ini bertujuan untuk mendapatkan protokol kultur in vitro yang optimal dan komprehensif dalam rangka mendukung upaya konservasi dan reintroduksi jenis ini. Penelitian dilakukan dengan menggunakan rancangan acak lengkap, meliputi penyemaian biji, subkultur protokorm (subkultur 1), subkultur planlet (subkultur 2), dan aklimatisasi planlet. Tingkat perkecambahan biji $D$. spectabile tertinggi pada 3 BSS (bulan setelah semai) terdapat pada media modifikasi Knudson's C (92,59\%). Pada subkultur pertama, pertumbuhan daun dan akar tertinggi pada 4 BST (bulan setelah tanam) terdapat pada media modifikasi Vacin dan Went $(4,12$ dan 2,13). Sedangkan pada subkultur kedua, pertumbuhan daun tertinggi pada 6 BST terdapat pada media Murashige dan Skoog dengan penambahan $100 \mathrm{~g} / \mathrm{l}$ pisang $(5,49)$, dan jumlah akar tertinggi serta penambahan panjang akar rata-rata tertinggi terdapat pada media Vacin dan Went setengah konsentrasi dengan penambahan $100 \mathrm{~g} / \mathrm{l}$ pisang $(7,05$ dan $0,47 \mathrm{~cm})$. Planlet teraklimatisasi dengan baik pada media campuran pakis cacah dan lumut sphagnum (2:1).
\end{abstract}

Kata kunci: Dendrobium spectabile, in vitro, perkecambahan asimbiotik, perkembangan planlet

\begin{abstract}
Dendrobium spectabile (Blume) Miq. is one of Papuan orchids that is of economic value and threatened. At present, the optimal protocol for asymbiotic seed germination and planlet development of $D$. spectabile is not yet available. This research aimed to develop an optimal and comprehensive protocol for in vitro culture of $D$. spectabile to support the conservation and reintroduction of this species. The experiment was conducted using a completely random design, including seed sowing, protocorm subculture (subculture 1), plantlet subculture (subculture 2), and plantlet acclimatization. The highest germination rate at 3 MAS (months after sowing) was found in modified Knudson's C (92.59\%). The first subculture at 4 MAP (months after planting) showed that the highest leaf and root growths were found in modified Vacin and Went (4.12 and 2.13, respectively). The second subculture at 6 MAP showed that the highest leaf growth was found in full strength of Murashige and Skoog supplemented with $100 \mathrm{~g} / \mathrm{l}$ banana homogenate (5.49), while the highest number of roots and average root extension were found in half strength of Vacin and Went supplemented with $100 \mathrm{~g} / \mathrm{l}$ banana homogenate $(7.05$ and $0.47 \mathrm{~cm}$, respectively). The plantlets were best acclimatized in media consisting of tree fern fibre and sphagnum moss (2:1)
\end{abstract}

Keywords: asymbiotic germination, Dendrobium spectabile, in vitro, plantlet development 


\section{INTRODUCTION}

Orchids is one of the most diverse plant families. According to Dressler (2005), there are 2500 species of orchids in the world, with the genus Dendrobium is the most popular as ornamental plants. Species of Dendrobium are highly prized ornamental assets, primarily as potted plants with showy flowers that tend to have a long vase life (Vendrame et al. 2007). Some Dendrobium species also has medicinal and pharmaceutical values, such as Dendrobium candidum Wall ex Lindl. (as Dendrobium moniliforme (L.) Sw.), Dendrobium nobile Lindl., Dendrobium officinale Kimura \& Migo (as Dendrobium catenatum Lindl.) (da Silva \& Ng 2017), Dendrobium crumenatum Swartz, Dendrobium pachyphyllum (Kuntze) Bakh. f., Dendrobium planibulbe Lindl., Dendrobium purpureum Roxb, Dendrobium salaccense (Blume) Lindl., and Dendrobium subulatum (Blume) Lindl. (Teoh 2019).

One important species of the genus is Dendrobium spectabile (Blume) Miq. This epiphytic orchid can only be found in Indonesian Papua and Papua New Guinea, Bougainville and Solomon Islands (Cribb 1983, Lavarack et al. 2000). It grows in swampy lowland forest and lower montane forest up to about $1000 \mathrm{~m}$ above sea level (Lavarack et al. 2000). This species is noted for its spectacular twisted flowers. The flowers are large, yellow, usually with maroon mottled sepals and petals, maroon lined lip, and with a white callus (Cribb 1983). The inflorescence consists of 20 flowers, each $4-8 \mathrm{~cm}$ across, distinctively twisted in all their parts, and blooms for several weeks (Lavarack et al. 2000).

The unique characteristics of $D$. spectabile's flower make this orchid has high commercial value. Consequently, this species is threatened by over collecting in the wild, in addition to deforestation. According to Global Forest Watch (2020), 85\% of tree cover loss in Papua occurred within natural forests from 2013 to 2018. This species has also been listed in the CITES Appendix II (CITES 2020). Therefore, this species requires conservation efforts to maintain its population in the wild.

Ex situ conservation for this orchid can be done by collecting a few plants from the wild and propagating it in botanic gardens. Dendrobium is conventionally propagated by splitting bulbs and keikis, or vegetative cuttings, but these are very slow and laborious methods that result only a few propagules in a year (Venturieri \& Pickscius 2013). Tissue culture, on the other hand, provides an alternative solution for producing a large number of plantlets within a limited period of time.

Asymbiotic seed propagation through tissue culture has major importance for the conservation and propagation of wild species because it can maintain the genetic diversity of the species. Material derived from seed, is representing a broader sample of genetic diversity which is important for the reintroduction of the species to the wild (Akeroyd \& Jackson 1995). Orchid propagation by seed results in high genetic variation of progeny (da Silva et al. 2015).

Various efforts using seeds explants of other Dendrobium species had been carried out by many researchers, such as Dendrobium tosaense Makino (as Dendrobium catenatum Lindl.) (Lo et al. 2004), Dendrobium fimbriatum Hook. (Sharma et al. 2005), Dendrobium nobile Lindl. (Vasudevan \& van Staden 2010), Dendrobium aphyllum (Roxb.) C.E.C. Fischer (Hossain et al. 2013), Dendrobium nobile hybrids (Udomdee et al. 2014), Dendrobium 'Iriana Jokowi' (Rahayu 2016), and Dendrobium lasianthera J.J. Sm. (Utami et al. 2017).

In vitro asymbiotic germination of Dendrobium seeds were influenced by several factors, such as medium composition, culture conditions, and explant age (da Silva et al. 2015). Murashige and Skoog (MS), half strength Murashige and Skoog (1/2 MS), Knudson's C (KC), and Vacin and Went (VW) were commonly used as basal culture medium for Dendrobium seed germination (Lo et al. 2004, Vasudevan \& van Staden 2010, Hossain et al. 2013, Udomdee et al. 2014, da Silva et al. 2015, Utami et al. 2017). Diverse organic compounds (malt, yeast, casein, peptone) and natural supplements (banana homogenate, coconut water, potato homogenate, bean sprout extract, and tomato juice) added to the media could affect (improve or inhibit) Dendrobium germination (Hossain et al. 2013, da Silva et al. 2015, Rahayu 2016, Utami et al. 2017).

Periodicity of light is a crucial factor that influences seed germination. Periodicity of light frequently used for inducing orchid seed germination are 12/12,14/10,16/8, (day/night) 
photoperiod (Lo et al. 2004, Vasudevan \& van Staden 2010, Hossain et al. 2013, Udomdee et al. 2014, Rahayu 2016, Utami et al. 2017).

The maturity of seeds affects the germination rate of orchid seeds. Mature seeds were usually used in in vitro germination of Dendrobium. About 3.3-4.7 months are required for Dendrobium seed to mature (da Silva et al. 2015). Dendrobium tosaense (as D. catenatum) took 3-4 months to become mature (Lo et al. 2004), D. 'Iriana Jokowi' took 4.5 months (Rahayu 2016), D. lasianthera took 3.5 months (Utami et al. 2017), while D. spectabile took 8.5 months to become mature (Santoso et al. 2014). Fruit maturity of D. spectabile can be identified from seed capsules with yellowish green coloration, supple fruit texture, and yellow seeds (Santoso et al. 2014). According to Udomdee et al. (2014), seed size increased and seed color changed from white to light green to creamy yellow during development of capsules of $D$. nobile hybrids from 2-5 months.

Kebun Raya Bogor (KRB) has D. spectabile as both living plant collection and in vitro plantlets. According to KRB collection database, the species was collected from Papua in 2000, 2004, and 2008. However, only one specimen is currently available in living collection which never flowered. It is very unfortunate since this orchid was also reputed for its rarity in terms flowering and fruiting (Lavarack et al. 2000). The in vitro plantlets collections of this species at KRB tend to grow shoots only, rather than develop into normal healthy plantlets with robust roots system to support the acclimatization process.

Previous in vitro culture experiments for D. spectabile had been carried out by Nuraini et al. (2011), Santoso et al. (2014), and Deswiniyanti (2015). Nuraini et al. (2011) used globular protocorms aged seven months after sowing (7 MAS) and cultured in Hyponex $(1 \mathrm{~g} / \mathrm{l})$ combined with yeast extract ( 1 and $1.25 \mathrm{~g} / \mathrm{l})$. This method resulted in high number of leaves (6), roots (2.2), length of roots $(0.6 \mathrm{~cm})$ and plantlet height $(1.6 \mathrm{~cm})$ at four months after planting (4 MAP). They showed that the plantlets required subculture and could not be acclimatized since the plantlets were small without a robust root system.

Santoso et al. (2014) used MUS medium (which was a modified form of VW basic medium) for in vitro germination of 8.5 months after pollinating seeds of $D$. spectabile. MUS medium was composed of $200 \mathrm{mg}$ of tricalsium phospate $\mathrm{CC}_{3}$ $\left.\left(\mathrm{PO}_{4}\right)_{2}\right), 525 \mathrm{mg}$ of potassium nitrate $\left(\mathrm{KNO}_{3}\right), 250 \mathrm{mg}$ of monopotassium phospate $\left(\mathrm{KH}_{3} \mathrm{PO}_{4}\right), 500 \mathrm{mg}$ of ammonium sulphate $\left(\left(\mathrm{NH}_{4}\right) \mathrm{SO}_{4}\right), 28 \mathrm{mg}$ of ferric tartrate $\left(\mathrm{Fe}_{2}\left(\mathrm{C}_{6} \mathrm{H}_{4} \mathrm{O}_{6}\right)_{3}\right), 250 \mathrm{mg}$ of magnesium sulphate $\left(\mathrm{MgSO}_{4} .7 \mathrm{H}_{2} \mathrm{O}\right), 7.5 \mathrm{mg}$ of mangane sulphate $\left(\mathrm{MnSO}_{4} .4 \mathrm{H}_{2} \mathrm{O}\right), 10 \mathrm{mg}$ of mio-inositol, 0.5 $\mathrm{mg}$ of thiamin $\mathrm{HCl}, 0.5 \mathrm{mg}$ of pyridoxine, $0.5 \mathrm{mg}$ of niacin, $20 \mathrm{~g}$ of glucose, $10 \mathrm{~g}$ of fructose, $20 \mathrm{ml}$ of cocconut water, and $7 \mathrm{~g}$ of agar. Germination process of $D$. spectabile seeds took up to 5 MAS. Germinated seeds were then subcultured into MUS media for three times, each took three months. Santoso et al. (2014) did not provide data on the growth of $D$. spectabile, but showed that it took 14 months from seed germination to seedling development until it was ready to be acclimatized.

Deswiniyanti (2015) sowed five months after pollinating seeds of $D$. spectabile on VW medium. One month after sowing (1 MAS) germinated seeds were then subcultured to VW medium modification added with $0.5 \mathrm{~g} / \mathrm{l}$ charcoal and $150 \mathrm{ml} / \mathrm{l}$ coconut water. Leaf number and seedling height of D. spectabile at 4 MAP were 3.45 and $2.65 \mathrm{~cm}$, respectively. No acclimatization was conducted.

No optimal protocols in asymbiotic seed germination and plantlet development of $D$. spectabile is currently available. The objective of this research was to develop an optimal and comprehensive protocol of in vitro culture of D. spectabile to support its conservation and reintroduction programs.

\section{MATERIALS AND METHODS}

\section{Seed germination test of Dendrobium spectabile}

Capsule of $D$. spectabile was donated by an orchid enthusiast, where the parent plant originated from Asmat District, Papua, Indonesia. Even though the capsule age was not known, it was considered as a mature capsule based on the characteristics proposed by Santoso et al. (2014) and Udomdee et al. (2014). The D. spectabile capsule was dipped in $95 \%$ ethyl alcohol and flamed, repeated three times. The sterilized capsule was then dissected longitudinally to extract its seeds. The seeds were sown on four different media and kept in the culture room at $25 \pm 2$ o C and $80 \%$ relative humidity under white fluorescent tubes 
with a 12/12-h (day/night) photoperiod. The seed germination experiment used a completely randomized design with one factor, namely four germination media commonly used at KRB Tissue Culture Laboratory: modified Hyponex (modified HS), modified Vacin and Went (modified VW), modified Knudson's C (modified KC), and Knudson's C (KCA) (Puspitaningtyas \& Handini 2014, Rahayu 2016).

Modified HS consisted of Hyponex fertilizer $0.5 \mathrm{~g} / \mathrm{l}$, potato homogenate $40 \mathrm{~g} / \mathrm{l}$, peptone $2 \mathrm{~g} / \mathrm{l}$, and active charcoal $1 \mathrm{~g} / \mathrm{l}$. Modified VW consisted of macronutrients and micronutrients Vacin and Went with addition of active charcoal $1 \mathrm{~g} / \mathrm{l}$, bean sprouts extract $100 \mathrm{~g} / \mathrm{l}$, tomato homogenate $100 \mathrm{~g} / \mathrm{l}$, coconut water $150 \mathrm{ml} / \mathrm{l}$, and NAA $10 \mathrm{mg} / \mathrm{l}$. Modified $\mathrm{KC}$ consisted of macronutrients and micronutrients Knudson C with addition of coconut water $150 \mathrm{ml} / \mathrm{l}$, bean sprouts extract $150 \mathrm{~g} / \mathrm{l}$, and active charcoal 1 g/l. KCA only contained macronutrients and micronutrients from Knudson's C. Each treatment (medium) consisted of four replications, with each replication consisted of 100-200 sown seeds (Puspitaningtyas \& Handini 2014).

Seed germination and protocorm developmental stages were examined using a stereomicroscope with an Olympus digital camera attached. Seed morphology was observed before and after germination. Seeds germination and protocorm development stages followed Vasudevan \& van Staden (2010). Germinated seeds, protocorms with rhizoids, and protocorms with pointed shoot apex and rhizoids at one, four, eight, and 12 weeks after sowing (1, 4, 8, and 12 WAS) were counted based on germinated seeds out of the 100-200 sown seed. The data were then analyzed with ANOVA and Duncan Test. The germination of D. spectabile was observed at three months after sowing (3 MAS), based on research of Rahayu (2016) and Utami et al. (2017) on other species.

\section{Subculture 1: Induction of leaves and roots from Dendrobium spectabile protocorms}

The 3 MAS protocorms with rhizoids and pointed shoot apex (stage 4) of $D$. spectabile were subcultured to induce leaf and root growth. Four media were used for this purpose, namely modified Growmore (T1A) consisted of Growmore fertilizer $0.5 \mathrm{~g} / \mathrm{l}$, peptone $2 \mathrm{~g} / \mathrm{l}$, banana homogenate $20 \mathrm{~g} / \mathrm{l}$, and active charcoal $1 \mathrm{~g} / \mathrm{l}$; VW supplemented with 20 $\mathrm{g} / \mathrm{l}$ banana homogenate and active charcoal $1 \mathrm{~g} / \mathrm{I}$ (T1V); modified KC; and modified VW. The $\mathrm{pH}$ of the medium was adjusted to 5.6. Experiments for leaf and root induction used a completely randomized design with one factor, namely the four media: T1A, T1V, modified KC, and modified VW. Each treatment consisted of three replications, and each replication consisted of five culture vessel; each culture vessel consisted of 10 protocorms. The number of leaves, roots, shoots, and length of roots were counted at four months after planting (4 MAP) (Utami et al. 2017). Data were analyzed with ANOVA. If the results were significantly different, then a Duncan Test was done in order to see the best media.

\section{Subculture 2: Induction of further growth of leaves and roots from Dendrobium spectabile plantlets}

Four months after planting (4 MAP) plantlets of $D$. spectabile resulted from subculture 1 were subcultured in four different media to induce further growth of leaves and roots in order to support the acclimatization process. The media used for this purpose were half strength of Murashige and Skoog supplemented with $100 \mathrm{~g} / \mathrm{l}$ banana homogenate $(1 / 2 \mathrm{P})$, half strength of Murashige and Skoog supplemented with $100 \mathrm{~g} / \mathrm{l}$ banana homogenate and $10 \mathrm{mg} / \mathrm{I} \mathrm{NAA} \mathrm{(1/2P10),} \mathrm{full}$ strength of Murashige and Skoog supplemented with $100 \mathrm{~g} / \mathrm{l}$ banana homogenate (MP), and half strength of Vacin and Went supplemented with 100 $\mathrm{g} / \mathrm{l}$ banana homogenate $(1 / 2 \mathrm{VT})$.

Experiments for further growth of leaves and roots used a completely randomized design with one factor, namely the four media: $1 / 2 \mathrm{P}, 1 / 2 \mathrm{P} 10$, $M P$, and $1 / 2 V T$. Each medium consisted of three replications, and each replication consisted of five culture vessels, each culture vessel contained five plantlets. The number of leaves, roots, shoots, and the length of root at the beginning of culture 10 MAP) were measured. The increase in the number of leaves, roots, shoots, and the length of roots were measured at 6 MAP in order to optimize the growth of the plantlets. Data were then analyzed with ANOVA. If the results were significantly different, then a Duncan Test was done in order to see the best media. 


\section{Acclimatization of plantlets}

The plantlets from each treatment with welldeveloped leaves, roots, and shoots were washed thoroughly under tap water for 2-3 minutes to remove traces of agar-gelled medium. These plantlets were then planted in plastic pots $(8 \mathrm{~cm}$ diameter) containing four different potting media: charcoal, a mixture of charcoal and tree fern fibre (2:1), tree fern block, and a mixture of tree fern fibre and sphagnum moss (2:1). The acclimatized seedlings were kept in the greenhouse. They were kept inside a plastic UV to maintain high humidity (above 90\%) and watered every day.

Each treatment consisted of three replications, and each replication consisted of 10 plastic pots; one seedling in each pot. The growth of new leaves, roots, and shoots were counted after six weeks of planting ( 6 WAP). Data were then analyzed with ANOVA and Duncan Test.

\section{RESULTS AND DISCUSSION}

\section{Seed germination test of Dendrobium spectabile}

Embryo of $D$. spectabile is located in the center of the seed. Each seed of $D$. spectabile consisted of a testa and an embryo without endosperms (Figure 1A). Observation at 3 MAS showed that germination rate ranged between 88.03-92.59\%. The germination rates of $D$. spectabile in the modified KC, HS, KCA, and modified VW were 92.58\%, 89.24\%, 88.32\%, and $88.03 \%$, respectively (Table 1 ). Orchid plants produced numerous minute seeds; each seed contained insufficient nutrient required for germination (da Silva et al. 2015). The seeds of $D$. spectabile were able to germinate well on all four tested media (Table 1). This showed that the four tested media provided the macronutrients and micronutrients needed for the seeds to germinate.

The high germination rate was also probably due to the capsule used in this study contained mature seeds with a high percentage of viable seeds that could germinate under in vitro asymbiotic conditions (da Silva et al. 2015). A three months old capsule of $D$. tosaense as $D$. catenatum) showed higher germination compared to a two months old capsule (Lo et al. 2004). Vasudevan \& van Staden (2010) also showed that the mature seeds of $D$. nobile resulted in a substantially greater germination rate compared to that of immature seeds. Udomdee et al. (2014) showed that immature seeds from a two months old capsule of D. nobile hybrids did not germinate and subsequently died after sowing, because the embryos were still under-developed and the ovules remained in white color when it should have been yellowish if ripen. The highest germination percentage was observed from four months old capsules of $D$. nobile hybrids. Rahayu (2016) also showed a high rate of germination rate for mature seeds (four months old) of $D$. 'Iriana Jokowi'.

Although seeds of $D$. spectabile started to germinate at 1 WAS, further growth and development of the seeds varied among all four tested media (Figure 2). The mean number of ungerminated seeds, germinated seeds, and protocorms with rhizoids after 3 MAS was not significantly different among the four tested media (Table 1). On the other hand, the mean number of protocorms with pointed shoot apex and rhizoids in modified KC media was much higher than those in HS media (106.75 protocorms and 13.5 protocorms, respectively). Observations on seed germination and development of plantlets at 1, 4, 8, and 12 WAS showed there was an increase in germinating seeds, protocorms with rhizoids, and protocorms with rhizoids and pointed shoot apex in all media tested (Figure 2A, B, C). The best germination and development trends were seen in the seeds cultured in modified KC and modified VW media.

Utami et al. (2017) showed that $D$. lasianthera cultured in $\mathrm{VW}$ produced a germination rate of $100 \%$. Germination rate of $D$. fimbriatum's seeds cultured in VW produced 80$90 \%$ of seeds that developed into protocorms (Sharma et al. 2005). Lo et al. (2004), however, showed that KC and VW were the least effective media for the germination of $D$. tosaense's seeds. Hossain et al. (2013) also showed low germination rate of $D$. aphyllum's seed in KC. These works showed that the best media for orchid seed germination were specific for each species.

Good germination and development trend in modified KC and modified VW was probably due to the addition of various organic material in the medium, such as coconut water, bean sprout extract, and tomato homogenate. According to Thorpe et al. (2008), coconut water contained amino acids, organic acids, nucleic acids, purines, sugars, sugar alcohols, vitamins, growth substances, 


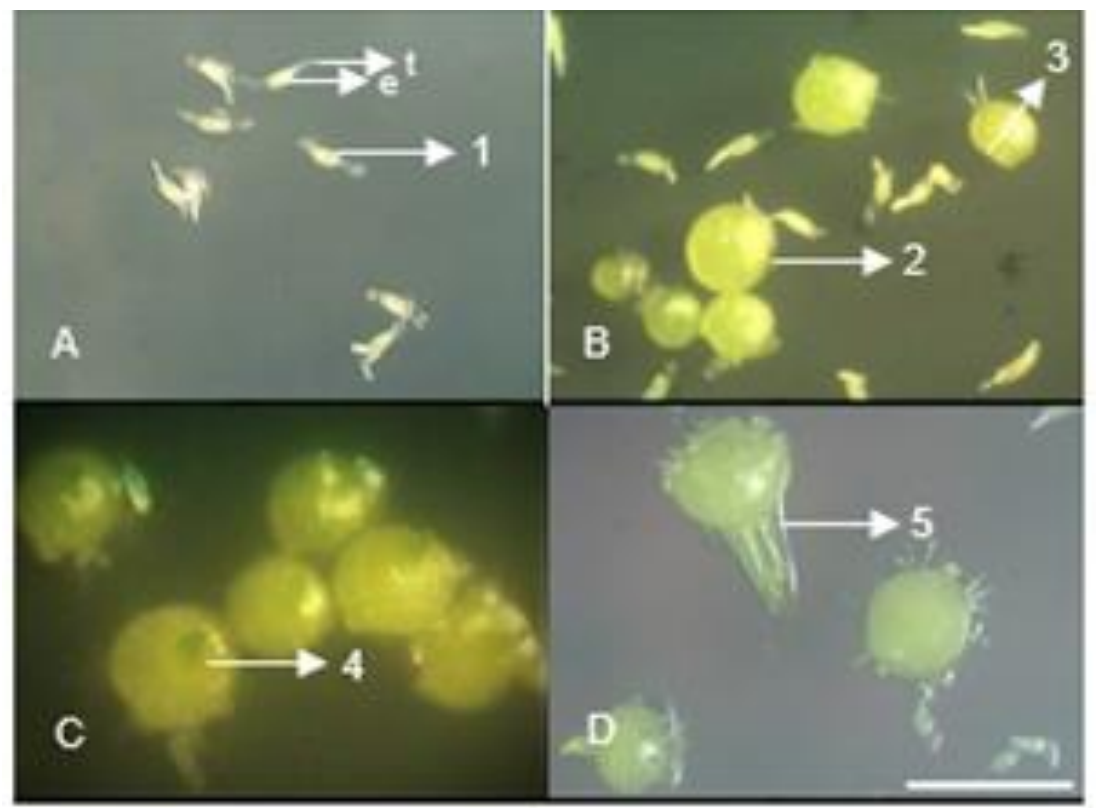

Figure 1. The development stages of seeds and protocorms of Dendrobium spectabile: A) Seeds of $D$. spectabile showing testa $(\mathrm{t})$ and embryo (e); A-D showing germination stages: 1) imbibed seed, swollen, still covered by testa, 2) enlarge embryo, seed coat ruptured (germination), 3) protocorm with rhizoids, 4) protocorms with pointed shoot apex and rhizoids (appearance of shoot apex), 5) emergence of first leaf. Magnification of 40x. Scale bar $=0.5 \mathrm{~mm}$

Table 1. Effects of media on seed germination and protocorm development of Dendrobium spectabile at 3 MAS (months after sowing)

\begin{tabular}{lccccc}
\hline & & \multicolumn{4}{c}{ Mean } \\
\cline { 3 - 6 } \multicolumn{1}{c}{ Media } & $\begin{array}{c}\text { Germination } \\
\text { rate (\%) }\end{array}$ & $\begin{array}{c}\text { Un-germinated } \\
\text { seeds }\end{array}$ & $\begin{array}{c}\text { Germinated } \\
\text { seeds }\end{array}$ & $\begin{array}{c}\text { Protocorms } \\
\text { with rhizoids }\end{array}$ & $\begin{array}{c}\text { Protocorms with } \\
\text { pointed shoot } \\
\text { apex and rhizoids }\end{array}$ \\
\hline HS & 89.24 & 20.25 & 168.00 & 35.25 & $13.50^{\mathrm{b}}$ \\
Modified VW & 88.03 & 24.50 & 180.25 & 73.00 & $73.00^{\mathrm{ab}}$ \\
Modified KC & 92.59 & 15.50 & 193.75 & 106.75 & $106.75^{\mathrm{a}}$ \\
KCA & 88.32 & 23.25 & 175.75 & 27.50 & $23.75^{\mathrm{ab}}$ \\
\hline
\end{tabular}

Values followed by different letters within a column are significantly different at $\mathrm{P}<0.05$ according to DMRT

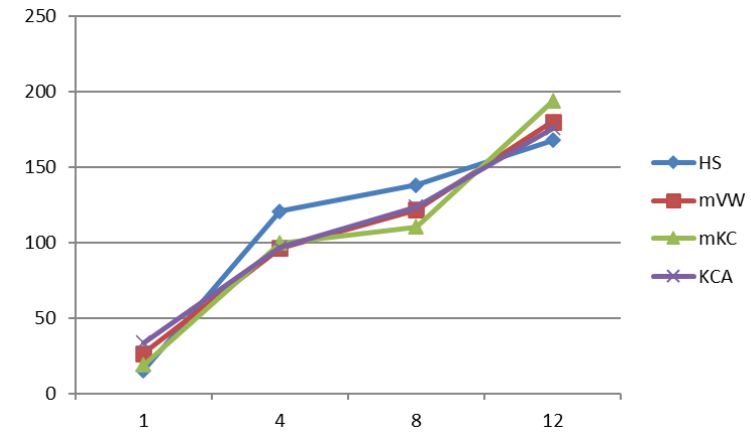

A)

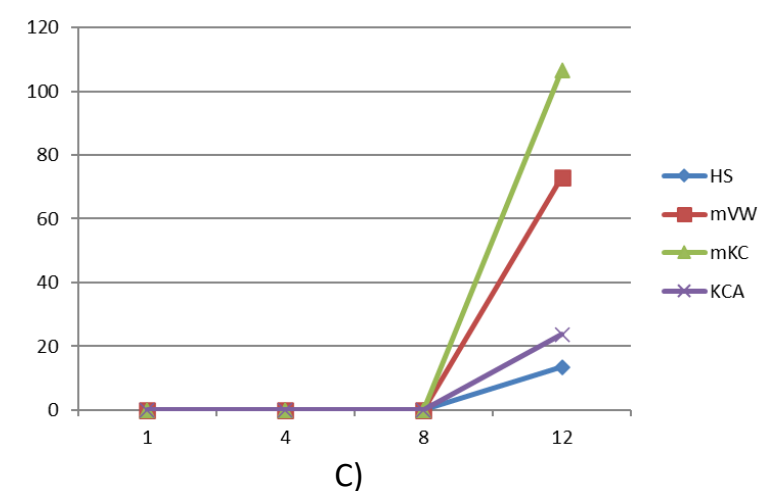

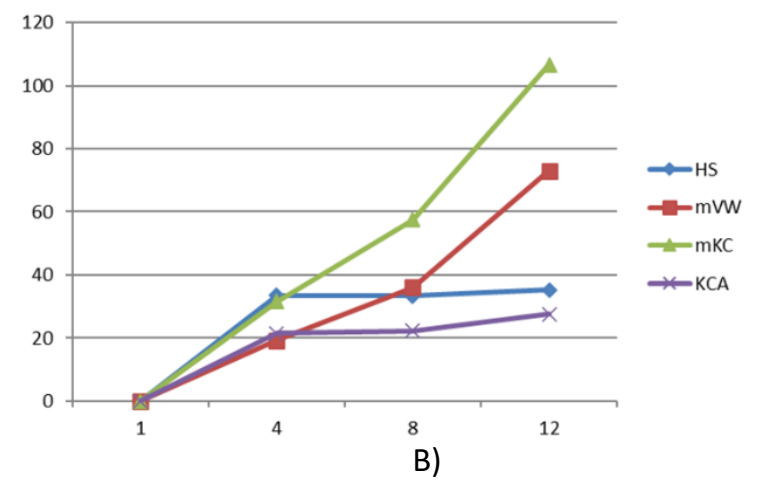

Figure 2. Effects of media on seed germination and protocorm development of Dendrobium spectabile at $1,4,8$, and 12 WAS (weeks after sowing): A) germinated seeds, B) protocorms with rhizoids, C) protocorms with pointed shoot apex and rhizoids. $\mathrm{HS}=$ Hyponex, $\mathrm{mVW}=$ modified Vacin and Went, $\mathrm{mKC}=$ modified Knudson's C, KCA = Knudson's 
minerals, and plant hormones. Winarto \& da Silva (2015) stated that coconut water was used to induce cell division, promote morphogenesis and accelerate the multiplication of protocorm like bodies (PLBs) in orchid's in vitro culture. Application of $150 \mathrm{ml} / \mathrm{l}$ coconut water in 1/2 MS medium increased the growth and proliferation capacity of Dendrobium 'Gradita 31'. According to Amilah \& Astuti (2006), bean sprout extract contained several essential vitamins and minerals, namely vitamin C, Thiamin, Riboflavin, Niasin, Vitamin B, $\beta$-karotein, Vitamin A, Vitamin E; and minerals calsium (Ca), ferrum (Fe), magnesium $(\mathrm{Mg})$, phosphor $(\mathrm{P})$, sodium $(\mathrm{Na})$, zinc $(\mathrm{Zn})$, copper $(\mathrm{Cu})$, and mangan (Mn).

Tomatoes homogenate contained sugar and antioxidants including vitamin $\mathrm{C}$ that stimulated seed germination and the growth of protocorm (Semiarti et al. 2010). Tomato extract in VW medium promoted protocorm's growth of Dendrobium bigibbum Lindl. (as Dendrobium phalaenopsis Fitzg.) (Setiari et al. 2016). Lycopene in tomato extract acted as an antioxidant that was required as a trigger for embryo development initiation. Tomato homogenate also contained $\mathrm{K}$ elements that facilitated the formation of water sac within the cell walls, and made it easier to absorb water (George \& Sherington 1984), thus it made embryo more susceptible to swelling. When embryo swelled, testa opened and released the embryo within, thereby accelerating germination (Setiari et al. 2016).

The development stages of $D$. spectabile's seeds and protocorms in all four tested germination media (Figure 1) were generally in line with the results by Vasudevan \& van Staden (2010), Hossain et al. (2013), Udomdee et al. (2014), and Rahayu (2016) of different species of Dendrobium. All of these works showed that the developmental stages started with imbibed seed, swollen, still covered by testa (stage 1). Stage 2 was indicated by enlarge embryo and ruptured seed coat (germination). At stage 3, protocorms developed rhizoids. Subsequently, at stage 4, protocorms were armed with rhizoids and pointed shoot apex (appearance of shoot apex). Then at stage 5, first leaf was emerged and further development of the plantlet was shown. Stage 1 and stage 2 on germination of D. spectabile were started at 1 WAS, stage 3 at 4
WAS, stage 4 at 9 WAS, and stage 5 after 12 WAS (Figure 2).

\section{Subculture 1: Induction of leaves and roots from Dendrobium spectabile protocorms}

Protocorms of $D$. spectabile that were subcultured in induction media developed plantlets at 4 MAP. The highest mean number of leaves (4.12) and roots (2.13) and length of roots $(1.21 \mathrm{~cm})$ were observed on plantlets planted in VW, whereas the highest mean number of shoots (0.09) was observed in T1A (Table 2). It was probably due to the addition of organic material to the medium, such as bean sprouts extract, tomato homogenate, and coconut water. Addition of organic supplements in plant tissue culture had been investigated by a number of workers. The addition of bean sprouts extract in culture media applied to 'unti sayang' banana (Musa x paradisiaca L.) showed that the bean sprouts extract provided significant influences on plantlet height, leaf number, root length, and root number (Jufri et al. 2014). The fastest rate of embryo development and the formation of shoot apical meristem prior to the emergence of leaf primordia of Phalaenopsis amabilis Blume was achieved by New Phalaenopsis medium supplemented with both coconut water and tomato homogenate (Semiarti et al. 2010). The addition of tomato homogenate in culture media was also effective for the germination of Geodorum densiflorum (Lam.) Schltr. (Mutukhrisnan et al. 2013). The tomato homogenate contained carotene, vitamin C, K, lycopene and other antioxidants which were not detected in coconut water that affect the growth and development of cells (Semiarti et al. 2010, Mutukhrisnan et al. 2013).

Table 2. Growth of plantlets of Dendrobium spectabile on the roots and leaves induction media at 4 MAP (months after planting)

\begin{tabular}{lcccc}
\hline \multirow{2}{*}{ Media } & \multicolumn{4}{c}{ Average number of } \\
\cline { 2 - 5 } & Leaves & Roots & $\begin{array}{c}\text { Length of } \\
\text { roots }(\mathrm{cm})\end{array}$ & Shoots \\
\hline T1A & $4.07^{\mathrm{a}}$ & $1.56^{\mathrm{b}}$ & $1.08^{\mathrm{ab}}$ & $0.09^{\mathrm{a}}$ \\
T1V & $3.98^{\mathrm{a}}$ & $1.16^{\mathrm{c}}$ & $1.21^{\mathrm{a}}$ & $0.04^{\mathrm{ab}}$ \\
Modified KC & $3.64^{\mathrm{b}}$ & $1.28^{\mathrm{c}}$ & $0.94^{\mathrm{b}}$ & $0.03^{\mathrm{b}}$ \\
VW & $4.12^{\mathrm{a}}$ & $2.13^{\mathrm{a}}$ & $1.21^{\mathrm{a}}$ & $0.02^{\mathrm{b}}$ \\
\hline Values followed by different letters & within a column are \\
significantly different at $\mathrm{P}<0.05$ according to DMRT
\end{tabular}


Fully-ripe tomato fruit contained basic nutrients and essential vitamins, as well as trace elements (Semiarti et al. 2010). Coconut water promoted the growth of leaves (3.5) and roots (5.0) of $D$. tosaense's (as $D$. catenatum) seedlings (Lo et al. 2004). According Utami et al. (2017), VW added with coconut water was able to produce plantlets of $D$. lasianthera with the highest number of roots and leaves.

\section{Subculture 2: Induction of further growth of leaves and roots of Dendrobium spectabile plantlets}

The subculture 2 at 6 MAP resulted in plantlets that were ready for acclimatization (Figure $3)$. The highest increase in leaf number was observed in MP (5.49), whereas that of new roots and root length was found in 1/2VT (7.05 roots and $0.47 \mathrm{~cm}$, respectively). There were no significant differences in the number of new shoots grown in all four media. The number of new shoots ranged from 2.83 to 3.08 (Table 3 ).

The highest number of leaves of $D$. spectabile plantlets on subculture 2 was found in $M P$ (5.49). However, the increase of roots in MP was much lower than in 1/2VT (3.28 and 7.05, respectively). MP medium consisted of banana homogenate. Udomdee et al. (2014) showed that the seeds of $D$. nobile hybrids germinated in medium without additional sucrose but with an addition of banana homogenate. Banana homogenate contributed to the basal level of carbon source. According to Sharrock \& Lusty (2000), ripe banana contained high sugar content which was 23.43/100 g raw edible portion. During ripening process, the sugar content in banana was in the approximate ratio of glucose : fructose : sucrose $=20: 15: 65$.

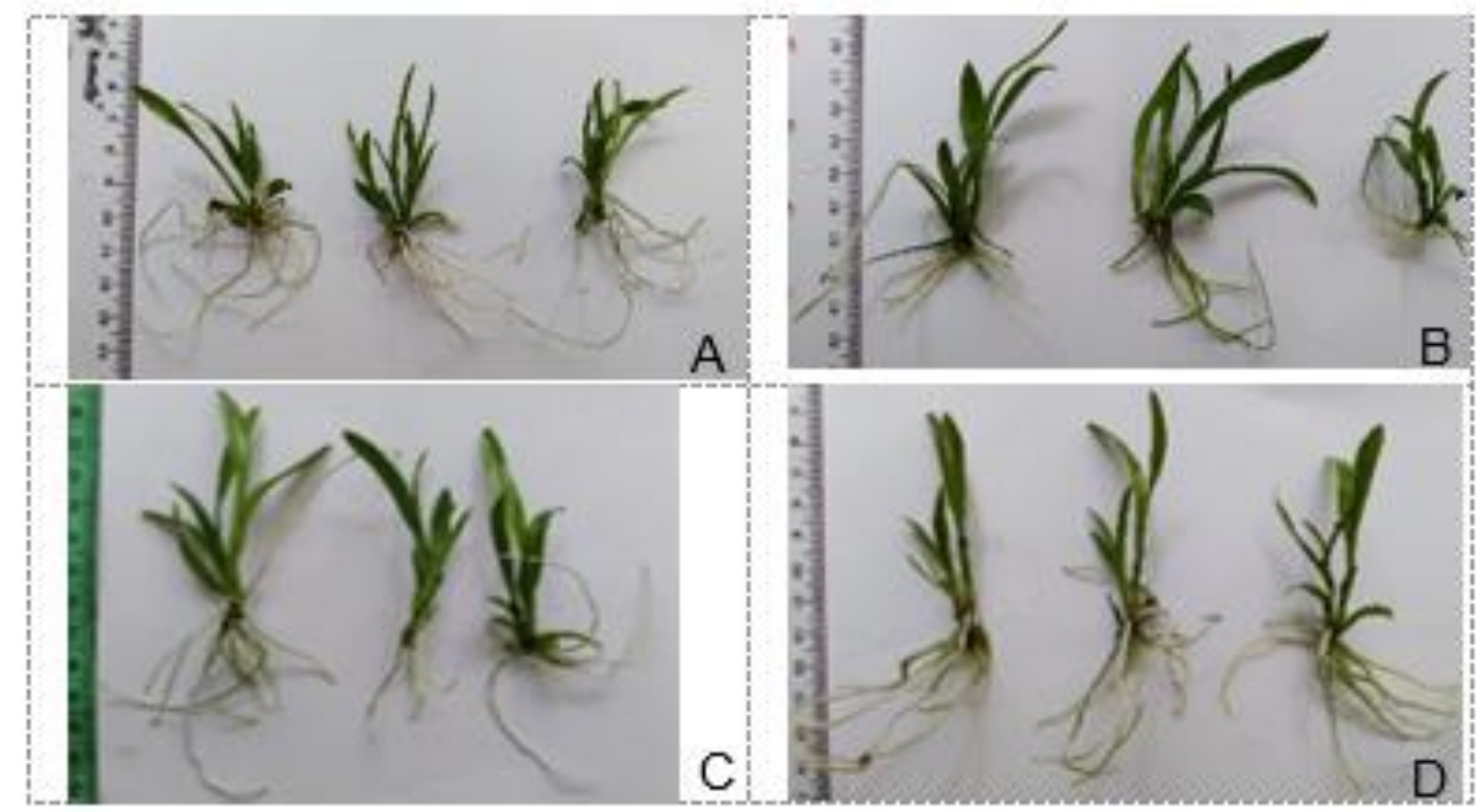

Figure 3. Plantlets of Dendrobium spectabile at $6 \mathrm{MAP}$ (months after planting) ready for acclimatization, subcultured in: A) $1 / 2 \mathrm{P}, \mathrm{B}) 1 / 2 \mathrm{P} 10, \mathrm{C}) \mathrm{MP}$, and D) 1/2VT media

Table 3. Growth of plantlets of $D$. spectabile on media for further induction of roots and leaves at 6 MAP (months after planting)

\begin{tabular}{lllll}
\hline \multirow{2}{*}{ Media } & \multicolumn{4}{c}{ Average number of } \\
\cline { 2 - 5 } & New leaves & New roots & Length of roots expansion & New shoot \\
\hline $1 / 2 \mathrm{P}$ & $4.73^{\mathrm{ab}}$ & $5.56^{\mathrm{b}}$ & $2.57^{\mathrm{b}}$ & 2.95 \\
$1 / 2 \mathrm{P} 10$ & $4.46^{\mathrm{b}}$ & $6.09^{\mathrm{b}}$ & $2.53^{\mathrm{b}}$ & 3.08 \\
MP & $5.49^{\mathrm{a}}$ & $3.28^{\mathrm{c}}$ & $1.14^{\mathrm{c}}$ & 2.83 \\
$1 / 2 \mathrm{VT}$ & $3.18^{\mathrm{c}}$ & $7.05^{\mathrm{a}}$ & $3.23^{\mathrm{a}}$ & 3.05 \\
\hline Values followed by different letters within a column are significantly different at $\mathrm{P}<0.05$ according to DMRT
\end{tabular}




\section{Acclimatization of plantlets}

The survival rate of $D$. spectabile seedlings at 6 WAP in all acclimatization media were 46.67$100 \%$ (Table 4$)$. The highest survival rate $(100 \%)$ was achieved by seedlings planted in a mixture of tree fern fibre and sphagnum moss (2:1) (Table 4, Figure $4)$, followed by those in a mixture of charcoal and tree fern fibre (2:1) (90\%) (Table 4). The lowest survival rate $(46.67 \%)$ was found in seedlings planted in charcoal. The highest number of new leaves, roots, and shoots were found in the seedlings grown in a mixture of tree fern fibre and sphagnum moss. The average of new leaves ranged from 0.37-2.5 (Table 4).

Similarly, Lo et al. (2004) found that the combination of tree fern and sphagnum moss was a more suitable substrate for $D$. tosaense's (as $D$. catenatum) seedlings survival than tree fern alone, with the survival rate was $87 \%$ in the former and $43 \%$ in the latter. Luo et al. (2008) also found that the same mixture was the most suitable substrate for plant survival of $D$. densiflorum. Formation of a functional root system in tissue cultured plantlets appeared to be an essential step for their survival after transplantation. In vitro roots remained functional and continued to grow during ex vitro acclimatization (da Silva et al. 2017). Therefore, a strong and robust root system should have been induced in in vitro plantlets before they were transferred outside.

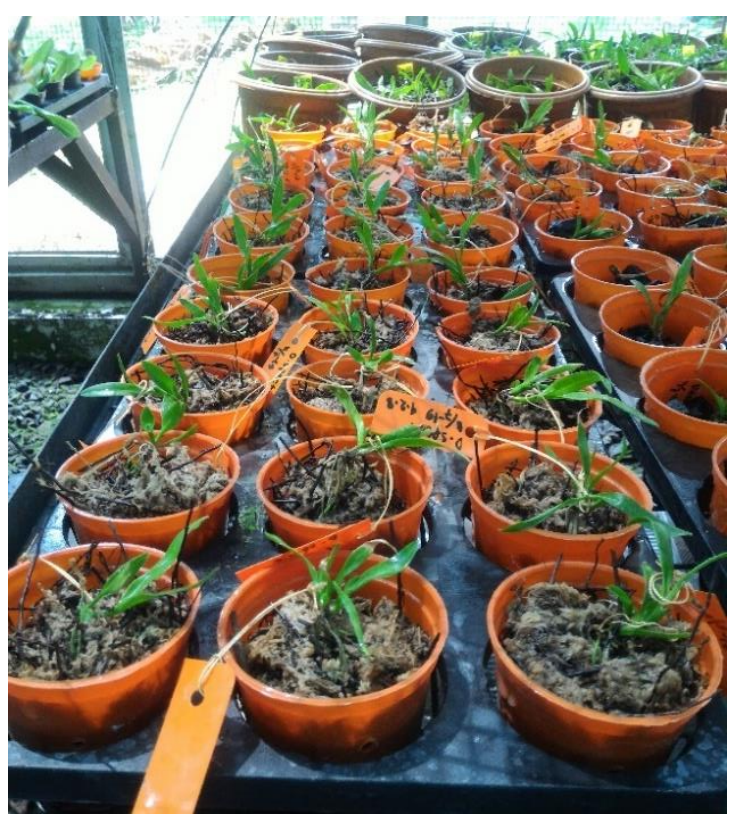

Figure 4. Seedlings of $D$. spectabile acclimatized in a mixture of tree fern fibre and sphagnum moss (2:1) at 6 WAP (weeks after planting)

Table 4. Survival rate and growth of seedlings of Dendrobium spectabile in four acclimatization media at 6 WAP (weeks after planting)

\begin{tabular}{lcccc}
\hline \multirow{2}{*}{ Media } & Survival rate & \multicolumn{3}{c}{ Average number of } \\
\cline { 3 - 5 } & $(\%)$ & New leaves & New roots & New shoots \\
\hline Charcoal & $46.67^{\mathrm{c}}$ & $0.37^{\mathrm{b}}$ & $0.00^{\mathrm{b}}$ & $0.07^{\mathrm{b}}$ \\
Charcoal and tree fern fibre (2:1) & $90.00^{\mathrm{a}}$ & $1.03^{\mathrm{b}}$ & $0.30^{\mathrm{ab}}$ & $0.43^{\mathrm{b}}$ \\
Tree fern block & $70.00^{\mathrm{b}}$ & $0.73^{\mathrm{b}}$ & $0.27^{\mathrm{ab}}$ & $0.47^{\mathrm{b}}$ \\
Tree fern fibre and sphagnum moss (2:1) & $100.00^{\mathrm{a}}$ & $2.50^{\mathrm{a}}$ & $0.47^{\mathrm{a}}$ & $0.93^{\mathrm{a}}$ \\
\hline
\end{tabular}

Values followed by different letters within a column are significantly different at $\mathrm{P}<0.05$ according to DMRT

This research produced plantlets with strong and robust root system, because both potting mixture used in this research, i.e. tree fern fibre:sphagnum moss (2:1) and charcoal:tree fern fibre $(2: 1)$, had strong permeability and retained humidity. This was in line with da Silva et al. (2017) who reviewed different kinds of media to acclimatize in vitro-raised Dendrobium plantlets, namely bricks, charcoal pieces, pine bark, Cycas bark, cocopeat, coconut coir, sawdust, perlite, vermiculite, peat, and sphagnum moss. They concluded that sphagnum moss performed low $\mathrm{pH}$ and absorbed large quantities of water and mineral nutrients, and was best used for the acclimatization of Dendrobium plantlets.

\section{CONCLUSIONS}

An efficient and simple protocol for rapid production of $D$. spectabile using seeds has been established as follows: the high germination rate at 3 MAS was achieved when the seeds were cultured in modified Knudson's C. The protocorms were then grown on modified VW media for four months. Plantlets were further grown on full strength of Murashige and Skoog supplemented with $100 \mathrm{~g} / \mathrm{l}$ banana homogenate (MP) or half strength of Vacin 
and Went supplemented with $100 \mathrm{~g} / \mathrm{l}$ banana homogenate $(1 / 2 \mathrm{VT})$ for six months. A total of 13 months was required to produce plantlets that were ready for acclimatization. Seedlings of $D$. spectabile were then acclimatized on potting media consisting of mixture of tree fern fibre and sphagnum moss (2:1). This protocol can be applied to support ex situ conservation and reintroduction programs of $D$. spectabile to their natural habitat, or for a large-scale cultivation for the interest of ornamental products as it would ensure high production of plantlets.

\section{ACKNOWLEDGMENTS}

The authors would like to thank Ms. Febi Nazuar, an orchid enthusiast, who donated a capsule of $D$. spectabile. This project was made available through Kebun Raya Bogor's Tissue Culture Laboratory operational budget of 20182019. The authors would also like to thank the anonymous reviewers, who provided useful comments and suggestions to improve the quality of our manuscript. Our gratitude was also addressed to the staff and internship students at KRB Tissue Culture Laboratory for their kind assistance, and to the staff of Orchids Collection and Registration Collection of Kebun Raya Bogor for their information regarding $D$. spectabile database.

\section{REFERENCES}

Akeroyd J, Jackson PW. 1995. A Handbook for Botanic Gardens on the Reintroduction of Plants to the Wild. Botanic Gardens Conservation International, Surrey.

Amilah, Astuti Y. 2006. Pengaruh konsentrasi ekstrak taoge dan kacang hijau pada media Vacin and Went (VW) terhadap pertumbuhan kecambah anggrek bulan (Phalaenopsis amabilis L.). Bulletin Penelitian 9: 1-20.

CITES. 2020. Dendrobium spectabile. https://cites. org/eng/node/32192. (accessed 29 March 2020).

Cribb PJ. 1983. A Revision of the Antelope and "Latourea" Dendrobiums. The Royal Botanic Gardens, Kew.

da Silva JAT, Ng TB. 2017. The medicinal and pharmaceutical importance of Dendrobium species. Applied Microbiology and Biotechnology 101: 2227-2239. doi: 10.1007/s00253-017-8169-9.

da Silva JAT, Tsavkelova EA, Ng TB, Parthibhan S, Dobránszki J, Cardoso JC, Rao MV, Zeng S. 2015. Asymbiotic in vitro seed propagation of Dendrobium. Plant Cell Reports 34: 16851706. doi: 10.1007/s00299-015-1829-2.

da Silva JAT, Hossain MM, Sharma M, Dobránszki J, Cardoso JC, Songjun Z. 2017. Acclimatization of in vitro-derived Dendrobium. Horticultural Plant Journal 3(3): 110-124.

Deswiniyanti NW. 2015. In vitro propagation of native orchid Dendrobium spectabile (Blume) Miq. Proceedings of the Second International Orchid Symposium: 69-74.

Dressler RL. 2005. How many orchid species? Proceedings of the Second International Orchid Conservation Congress: 155-158.

George EF, Sherrington PD. 1984. Plant Propagation by Tissue Culture. Exegetics Limited, England.

Global Forest Watch. 2020. Indonesia. Papua. Forest change. (accessed 20 January 2020).

Hossain MM, Sharma M, Pathak P. 2013. In vitro propagation of Dendrobium aphyllum (Orchidaceae) - seed germination to flowering. Journal of Plant Biochemistry and Biotechnology 22(2): 157-167. doi:10.1007/ s13562-012-0124-3

Jufri N, Abdullah, Susanti D. 2014. The use of bean sprout extract as supplement for the growth of plaintain Unti Sayang (Musa paradisiaca L.) by tissue culture. Journal of Agricultural Studies 2(1): 99-106.

Lavarack B, Harris W, Stocker G. 2000. Dendrobium orchids. Periplus Edition Ltd., Singapore.

Lo SF, Nalawade SM, Kuo CL, Chen CL, Tsay HS. 2004. Asymbiotic germination of immature seeds, plantlet development and ex vitro establishment of plants of Dendrobium tosaense Makino - A medicinally important orchid. In Vitro Cellular Developmental Biology - Plant 40: 528-535.

Luo JP, Wang Y, Zha XQ, Huang L. 2008. Micropropagation of Dendrobium densiflorum Lindl. ex Wall. through protocorm-like bodies: Effects of plant growth regulators and lanthanoids. Plant 
Cell Tissue and Organ Culture 93: 333-340. doi: 10.1007/s11240-008-9381-1.

Mutukhrisnan S, Kumar TS, Rao MV. 2013. Effects of different media and organic additives on seed germination of Geodorum densiflorum (Lam) Schltr. - An endangered orchid. International Journal of Scientific Research: 23-26.

Nuraini, Hamidin E, Rizky WH. 2011. Growth and development of Dendrobium spectabile orchid protocorm to various combination alternative media in vitro. Prosiding Seminar Nasional Florikultur: 81-90.

Puspitaningtyas DM, Handini E. 2014. Penyimpanan biji anggrek Coelogyne spp. untuk konservasi ex situ. Buletin Kebun Raya 17(2): 101-112.

Rahayu EMD. 2016. Handling and propagation of Dendrobium 'Iriana Jokowi' in Bogor Botanic Gardens, Indonesia. Nusantara Bioscience 8(2): 258-263.

Santoso U, Manohara YSW, Rochiman K. 2014. Dendrobium spectabile (Blume) Miq. in vitro culture and its acclimatization on mus media with antimicrobial and alcoholic sugar supplementation. Journal of Biological Researches 20: 36-41.

Semiarti E, Indrianto A, Purwantoro $\mathrm{YH}$, Martiwi INA, Feroniasanti YML, Nadifah $F$, Mercuriana IS, Dwiyani R, Iwakawa H, Yoshioka Y, Machida Y, Machida C. 2010. High-frequency genetic transformation of Phalaenopsis amabilis orchid using tomato extract-enriched medium for the pre-culture of protocorms. Journal of Horticultural Science and Biotechnology 85(3): 205-210. doi: 10.1080/14620316.2010.1151265.

Setiari N, Purwantoro A, Moeljopawiro S, Semiarti E. 2016. Peptone and tomato extract induced early stage of embryo development of Dendrobium phalaenopsis orchid. Journal of Tropical Biodiversity and Biotechnology 1(2): 77-84.

Sharma R, De KK, Sharma B, Majumdar S. 2005. Micropropagation of Dendrobium fimbriatum Hook. by green pod culture. Journal of Plant Biology 48(2): 253-257.

Sharrock S, Lusty C. 2000. Nutritive value of banana. In: INIBAP annual report 1999. INIBAP: Montpellier (FRA): 28-31.
Teoh ES. 2019. Orchids as Aphrodisiac, Medicine or Food. Springer Nature, Switzerland.

Thorpe T, Stasolla C, Yeung EC, de Klerk GJ, Roberts A, George EF. 2008. The components of plant tissue culture media II: Organic additions, osmotic and $\mathrm{pH}$ effects, and support systems. In Goerge EF, Hall MA, De Klerk GJ (eds), Plant Propagation by Tissue Culture. Volume 1. The Background. 3rd ed. Springer, Dordrecht: 115-173.

Udomdee W, Wen PJ, Lee CY, Chin SW, Chen FC. 2014. Effect of sucrose concentration and seed maturity on in vitro germination of Dendrobium nobile hybrids. Plant Growth Regulator 72: 249-255. doi: 10.1007/ s10725-013-9856-x.

Utami ESW, Hariyanto S, Manuhara YSW. 2017. In vitro propagation of the endangered medicinal orchid Dendrobium lasianthera J.J.Sm. through mature seed culture. Asian Pacific Journal of Tropical Biomedicine 7(5): 406-410.

Vasudevan R, van Staden J. 2010. Fruit harvesting time and corresponding morphological changes of seed integuments influence in vitro seed germination of Dendrobium nobile Lindl. Plant Growth Regulator 60: 237-246. doi: 10.1007/s10725-009-9437-1.

Venturieri GA, Pickscius FJ. 2013. Propagation of noble dendrobium (Dendrobium nobile Lindl.) by cutting. Acta Scientiarum 35: $501-$ 504.

Vendrame WA, Carvalho VS, Dias JMM. 2007. In vitro germination and seedling development of cryopreserved Dendrobium hybrid mature seeds. Scientia Horticulturae 114: 188-193. doi: 10.1016/j.scienta.2007.06.006.

Winarto B, da Silva JAT. 2015. Use of coconut water and fertilizer for in vitro proliferation and plantlet production of Dendrobium 'Gradita 31'. In Vitro Cellular Developmental Biology - Plant 51: 303-314. doi:10.1007/s11627015-9683-z. 